\title{
Optimum Open Pit Design for Kenticha Tantalite Mine, Southern Ethiopia
}

\author{
Weldegebrial Haile ${ }^{1 *}$ and Bheemalingeswara Konka ${ }^{2,3}$ \\ ${ }^{1}$ School of Mines, Axum University, Shire Campus, Ethiopia (*weldegebrialh@gmail.com). \\ ${ }^{2}$ School of Earth Science, CNCS, P.O. Box. 231, Mekelle University, Mekelle, Ethiopia. \\ ${ }^{3}$ Department of Mining and Geological Engineering, Faculty of Engineering and Technology, \\ P.B. 16, Botswana International University of Science and Technology, Palapye, Botswana.
}

\begin{abstract}
The mining sector's share in Ethiopia's economy is gradually increasing. Among metallic mines, Legadembi for gold and Kenticha for tantalum are the main contributors. At Kenticha, the Ethiopian Mineral Development Share Company is producing tantalite concentrate of 40$60 \%$ grade by open pit mining. The mine area is comprised of the rocks of Neoproterozoic age, pegmatite, granite, serpentinite, and talc-chlorite schist. The ore-bearing pegmatite intruding the basement serpentinite, and talc schist rocks, is asymmetric, N-S trending, and locally affected by fractures and local faults. Mining, at present, is being done using conventional methods not by developing benches. An optimum open pit design is developed and its impact on the run of mine is evaluated based on the field data, technical mine report data, borehole data, tonnage data, grade data and mine survey. The suggested design has taken into account the mine drainage, bench design, haul road design, and mine waste dump design. Also keeping in view the future mining and production requirements. The suggested open pit mine design can minimize the dilution and improve the ore recovery.
\end{abstract}

Keywords: Kenticha mine, Tantalite, Optimum open pit design, Ethiopia.

\section{INTRODUCTION}

Mining activities in Ethiopia have been increasing gradually over the past two decades due to the liberalization policies of the government. This trend has attracted both national and international mining companies to explore for both metallic and industrial minerals in different parts of the country. Among metals, gold, tantalite and base metals are attracting the attention of the exploration and mining companies. Some of the local companies engaged in these activities are Ethiopian Mineral Development Share Company (EMDSC), National Mining Company, and Midrock, Ezana Mining Development Plc. EMDSC is carrying out both mining and processing of tantalite ore at Kenticha and exporting the tantalite concentrate. At present, Kenticha Ta deposit is the only mineable tantalite deposit in the country. Tantalite ore has been mined using open pit mining method since 1991. Processing was initially carried out using a pilot scale processing plant which was later expanded (EMDSC, 2010). According to USGS (2014) report the tantalite mine production at Kenticha has declined with time from above 40 to 10 million tons per year. The rank of the country among tantalite producing countries has also shifted from $5^{\text {th }}$ to $8^{\text {th }}$. Among the reasons for decline in production are the presence of uranium as inclusion and increasing dilution. In 
general, the effect of dilution can be significant and differ for different types of mining operations and nature of the deposits. It is obvious that dilution increases the cost of mining operations and causes a significant ore to be discarded as waste. Dilution varies from one mine site to another, but the effect of dilution is a major cause of ore loss in mining operations; for example, on an average dilution is considered to be about $5 \%$ for base metals in copper porphyry type of mineral deposits, and about $10 \%$ for precious and rare earth elements (Ebrahimi, 2013). So, controlling the dilution and improving the production is a major task in all mining operations. It is achieved by using efficient mine designs, good mining practices, efficient monitoring and control. The shape and size of an open-pit depends on certain factors which must be understood in the planning of the open-pit operation. Some of these factors are bench height, ore recovery, geology, grade and localization of the mineralization, extent of the deposit, topography, property boundaries, production rate, mining cost, processing cost, cutoff grade and pit slopes (Armstrong, 1990). Bench design is important in open pit mines and its design has an impact on the recovery of ore (Ramazan, 2007). The objective of operating an open pit mine is to achieve maximum ore recovery at the lowest possible cost and thus derive maximum profit (Ramazan and Dimitrakopoulos, 2013).

The main objective of developing optimum open pit design and pit optimization has to take into account vital factors such as: geological setting of the deposit and topography, grade distribution, cut-off grade, mineral reserve, geotechnical characteristics (to constrain bench height and slope stability), environmental constraints, mining and processing costs, recovery and mineral price (Frempong-Boakye, 2004; Amankwah, 2011; Baochie, 2013; Dongboi, 2013; Elias, 2013; and Akisa and Mireku-Gyimah, 2015).

In Kenticha mine, tantalite ore deposit occurs in 8 localities (locality 1, 2, 3, 4, 5, 6, 7 and 8). At present mining is confined to 2, 6 and 7 localities and the ore mined is lateritic and weathered ore. Primary ore is yet to be mined. At present, dominantly weathered ore is being mined at a depth of $30 \mathrm{~m}$ using conventional mining method without developing benches. Mining is expected to expand to other localities and also from weathered to primary ore in future. From the mining point of view, it is necessary to review the existing designs and visualize an open pit mine taking into account all localities. The expected optimal open pit mine design should also have properly developed haul roads (ramp) that suit the future downward advancement to exploit the primary ore (EMDSC, 2010). The average ore loss due to improper mining practices, and beneficiation is estimated to be around 5-10\% (USGS, 
2014; Weldegebrial et al., 2020). Thus, an effort was made to develop an optimum mine design to meet the future needs and minimize the ore losses.

\subsection{Study Area}

Kenticha mine is located in the Oromia region, southern Ethiopia about $550 \mathrm{~km}$ south of Addis Ababa and $52 \mathrm{~km}$ south of Shakiso town $(501920 \mathrm{mE}$ to $502440 \mathrm{mE}$ longitudes and $602640 \mathrm{mN}$ to $603640 \mathrm{mN}$ latitudes) (Fig 1). The elevation ranges from $1500 \mathrm{~m}$ to $1800 \mathrm{~m}$

(Fig 2). It is accessible by an asphalt road from Addis Ababa to Shakiso town (498 km), and by a gravel road from Shakiso to Kenticha $(52 \mathrm{~km})$.

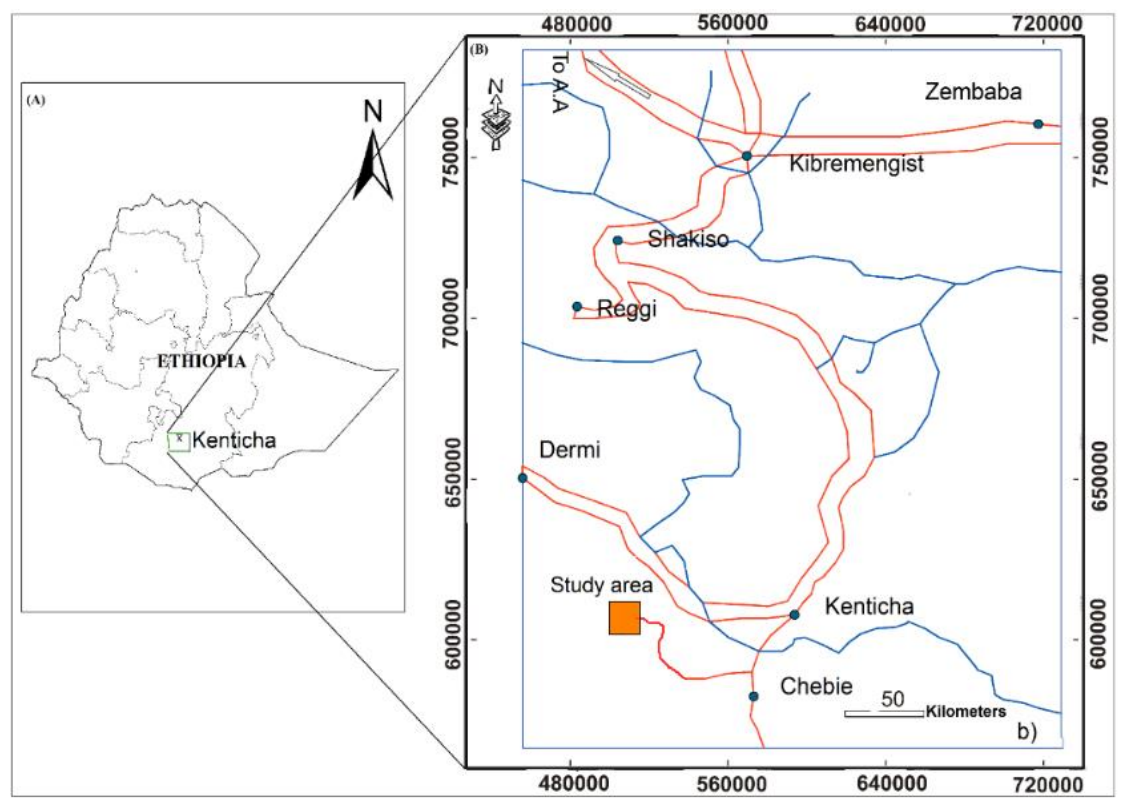

Figure 1. Location map of the study area A) Ethiopia, B) road and drainage.

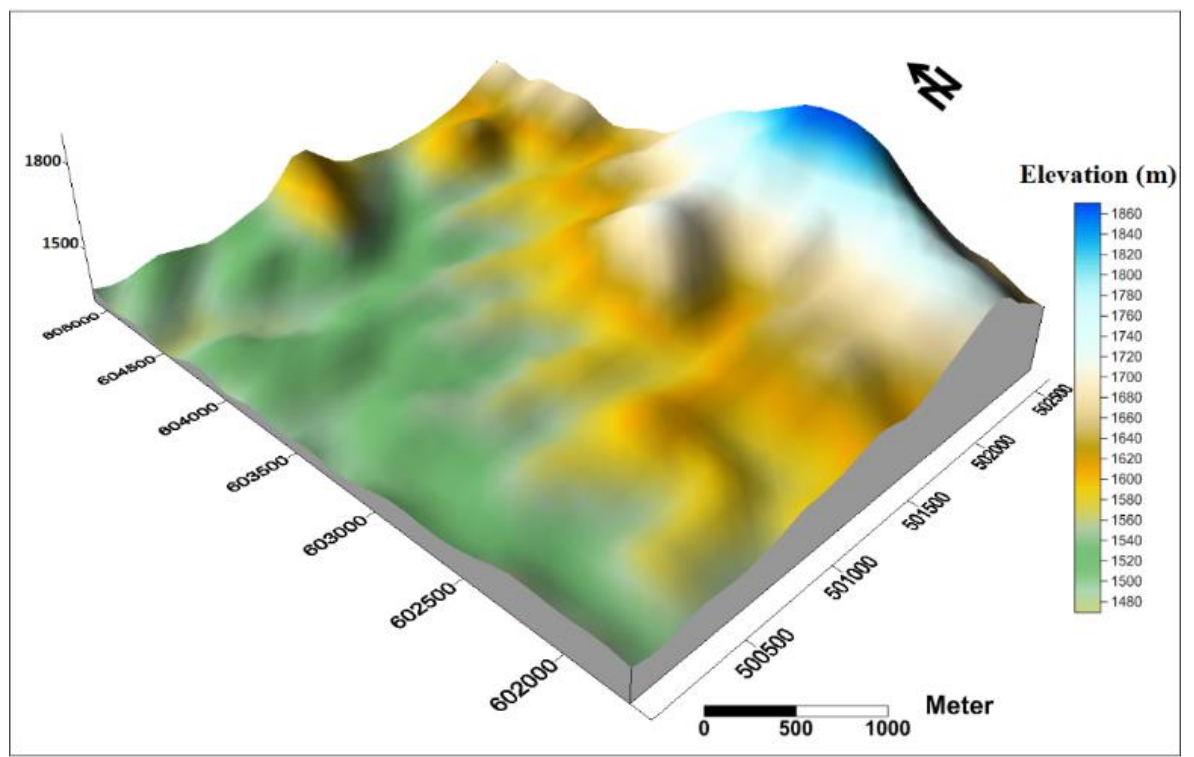

Figure 2. Physiographic set up of the study area developed using Surfer-9 software. 


\section{METHODOLOGY}

The following approaches were adopted to develop the optimum open pit design and evaluate its effect on the grade of the ore.

\subsection{Field observation and investigation}

This involved lithological and structural identification, relation between the ore and overburden materials, mining operations (starting from the excavation to haulage) used and recording of the UTM coordinate reading of the pegmatite ore body of the mine site. The geological map (Fig 3a) and the cross-section (Fig 3b) were developed using Google earth image of the study area as the base.

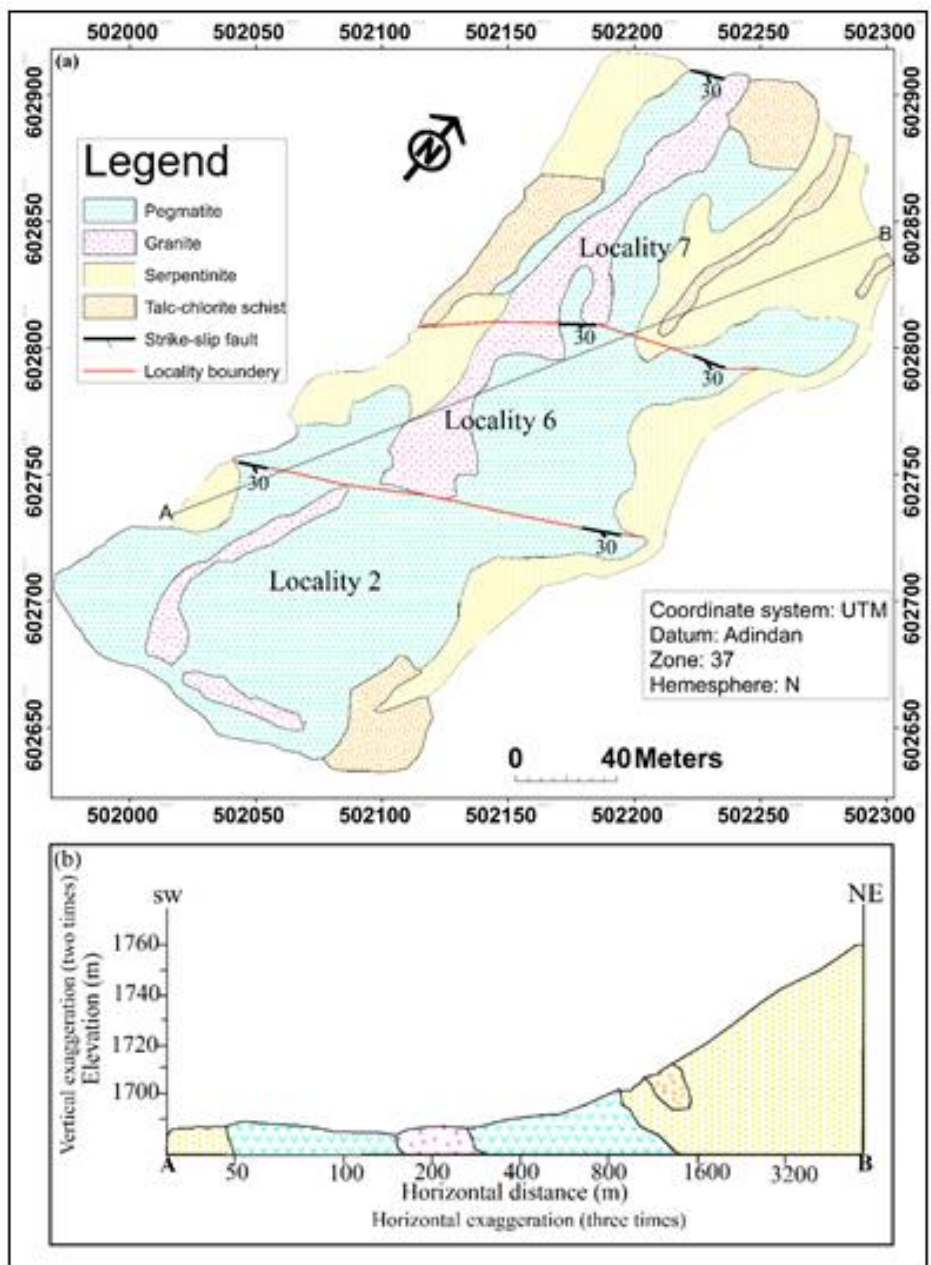

Figure 3 a) Geological map of the study area (after EMDSC, 2010), b) Cross-section map, profile along the line A-B of the study area.

Different lithologies, contacts and structural data were collected in the field and recorded. In the practical field visualization, each lithological distinctive feature was demarcated besides the Google Earth Image. It was followed by geo-referencing and digitizing clearly the fields demarcated lithological contacts in Arc GIS-10 software. The 
cross-section map (Fig 3b) was selected along a cross-sectional line A-B as it cuts through the maximum number of lithologies of the area in the geological map. This was developed by using recorded coordinate readings of each contact that touches the cross-section line; taking the readings and digitizing them by inserting the points into the Digital Elevation Model (DEM) of Ethiopia opened in Global mapper-12 and then by selecting the 3D path profile tool and connecting the digitized points. The section profile of the area was displayed and the profile section was saved in BMP file type and then added to Arc map. The remaining tasks were completed (fixing the vertical and horizontal scales, creating the shape file of each lithology, digitizing and editing it). To view the 3-D model of the mining area, the coordinate and elevation values were used as inputs and processed in Surfur-9 software (see Fig 2).

Table 1. Geotechnical properties of ores.

\begin{tabular}{|llccc|}
\hline Properties & Unit & Weathered ore & Semi-weathered ore & Primary ore \\
\hline Weight volume $\left(\gamma_{1}\right)$ & ton $/ \mathrm{m}^{3}$ & 1.7 & 2.1 & 2.7 \\
\hline Bulk volume $\left(\gamma_{2}\right)$ & ton $/ \mathrm{m}^{3}$ & 1.4 & $1.7-1.8$ & 2 \\
\hline Hardness coefficient $(\mathrm{f})$ & - & 0.8 & $1-2$ & $7-8$ \\
\hline Moisture content & $\%$ & $6-7$ & $6-7$ & $6-7$ \\
\hline
\end{tabular}

Table 2. The expansion coefficient of ore.

\begin{tabular}{|lcc|}
\hline Ore division & Hardness coefficient & Expansion coefficient \\
\hline Weathered ore & $0.7-0.8$ & 1.2 \\
\hline Semi-weathered ore & $1-2$ & 1.25 \\
\hline Primary ore & $7-8$ & $1.3-1.4$ \\
\hline
\end{tabular}

\subsection{Ore Sample Analysis}

This was done in Kenticha mine site using 44 boreholes and 274 test pits conducted by EMDSC. Among the boreholes drilled and pits tested, four representative samples were used systematically to check the geotechnical proprieties of the weathered, semi-weathered and primary ores. Each of the samples weighed $2.5 \mathrm{~kg}$ and were collected at depths of $10 \mathrm{~m}, 20$ $\mathrm{m}, 40 \mathrm{~m}$ and $80 \mathrm{~m}$. The samples were analysed and the results are summarized in tables 1 and 2 (major part of the data is from the company report).

\subsection{Previous Exploration and Mining related Data Interpretation}

It included geological data, mineral related data, borehole data, mine survey data, data related to tonnage and grade of the ore, data of the existing design, ore block data and surface mine works data. The data is compiled, analyzed, and interpreted. The optimal open pit design was 
done using Surpac-6.5.1 software. The interpreted company's data was used to determine the basic and design parameters such as: (See also Appendix 1)

A) Basic parameters:

Machinery height (ranges from $3 \mathrm{~m}$ to $5 \mathrm{~m}$ ) and width (ranges from $3 \mathrm{~m}$ to $4 \mathrm{~m}$ );

Nature of the deposit and host rock;

Exploration Lines (E.L) and bore-hole data;

Cut-off grade of $\mathrm{Ta}_{2} \mathrm{O}_{5}$; and

maximum depth of drillholes for blating;

EMDSC has analysed geotechnical characterstics of the ore, overburden and host rock (EMDSC, 2013) and details of the data are described below:

For the ore: Intensity: $\mathrm{f}=0.5 \sim 2$ (i.e, weathered ore, semi weathered ore); Volume weight: $1.7 \mathrm{t} / \mathrm{m}$, and Pile weight: $1.4 \mathrm{t} / \mathrm{m}$

For the Overburden: Rock intensity: $\mathrm{f}=5 \sim 7$ and Volume weight: $2.7 \mathrm{t} / \mathrm{m}$

For the host rock: Hardness $(\mathrm{H})$ of the host rock is ranging from 6 to 8 and this reveals the host rock is strong.

B) Design parameters:

Bench height $=10 \mathrm{~m}$ (the value is specified depending on the existing machinery height, nature of the ore strength and also cosiders the dilution impact);

Bench width $=8 \mathrm{~m}$ (based on the machinery width);

Bench slope $=42^{\circ}$ (being the ore and overburden materials are tilted, the selected value could be averagely suit to avoid slope failure and further will minimize the dilution effect); OPSA $=38^{\circ}$ (for both the soft and hard rock formation);

Haul road width $=7-9 \mathrm{~m}$ (it is specified depending on possiblity to pass two trucks and could assure two way of traffic flow);

Average slope $=3 \%$;

Maximum slope $=8 \%$; and

Curve radius $=9-12 \mathrm{~m}$ (to keep vissiblity of machineries and it better maintains safety).

The above parameters were the input to Gemcom Surpac 6.5.1 software and the following detail activities were conducted.

Step1:Displaying the survey (topographic) data into the software window;

Step2: Adding the drill hole data and ovelaying them within the survey data which is early open data;

Step3: Inputting the drill hole data cordinates that define the orebody in the required fields to be used as a bench marks;

Step4: Delineating the orebody using the bench marks delineated from the solid dtm of the software; 
Step5: Specifying the bottom and top pit limits depending on the maximum thickness (110 m) and lateral extent of the orebody determined from the drill hole and survey data;

Step6: Starting the design of the bench and the zigzag type of haul road design from bottom of the pit to the top using all the design parameters determined in earlier steps.

\section{GEOLOGY OF THE AREA}

The study area mainly consists of talc-chlorite schist, serpentinite, granite and pegmatite rocks with minor structural elements like fractures and faults. Among the rocks, pegmatite covers the major part. It is a coarse grained rock and hosts the rare metals $\mathrm{Ta}$ and $\mathrm{Nb}$ (Fig 3). It is followed by medium to coarse grained pink and light gray granite. Granite poses a challenge in surface mining because once the mantle of the weathered ore is removed, the quartz core of pegmatite appears on the pegmatite-granite rocks that requires shifting of the mining operations to the other localities. Serpentinite next to granite, shows light green color with fine grained texture and is found in contact with the talc-chlorite schist. Serpentinite is the main country rock for the pegmatite deposit. The schist is fine grained, light green and typically shows soapy nature.

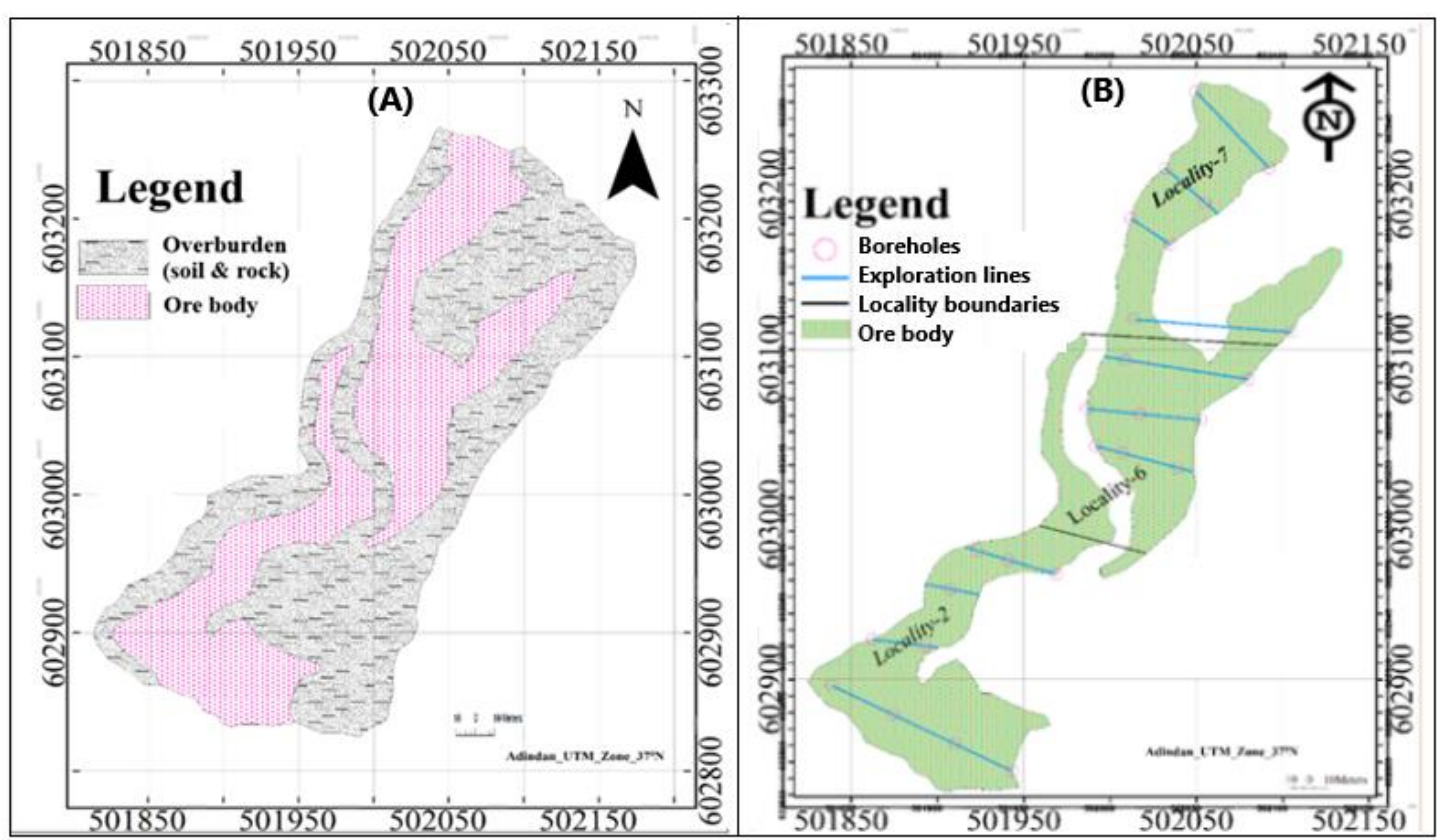

Figure 4. (A) Plan view of the deposit and overburden materials (modified after EMDSC, 2010); (B) Outcrop map of the pegmatite body with boreholes drilled along the exploration lines (modified after EMDSC, 2010).

Kenticha deposit is slightly affected by geological structures related to neo-tectonics. Due to mining activities the structures are disturbed and covered, and difficult to distinguish them clearly including in the borehole logs. The observed structures include fractures, which 
are localized, closely spaced, mainly in granite-pegmatite rock (along the quartz core) trending $\mathrm{N} 45^{\circ} \mathrm{E}$. The deep-seated fault along which the pegmatite body formed shows northsouth strike direction (Fig 3) (Zerihun et al., 1995; Tadesse, 2009). The over burden is one of the causes of dilution of ore (Fig 4A). V-shaped valley observed during fieldwork suggests presence of a weak zone, possibly a strike-slip fault trending $\mathrm{N} 30^{\circ} \mathrm{E}$ with $30^{\circ}$ dip towards east (Fig 3a).

\subsection{Ore Geology}

The pegmatite deposit has an average length of $1,000 \mathrm{~m}$ and width $50 \mathrm{~m}$ and the width is similar in each of the three localities (localities 2, 6 and 7), but lengths of the ore body in the localities vary slightly (Figs 4 A \& B). The ore body is N-S trending and dipping towards east. Accordingly, it is suggested that the direction of mining be from west to east to have safe mining operations and also to minimise dilution during mining.

Three types of tantalite ore namely lateritic ore, weathered (oxidized) ore and primary ore were observed in the study area (Fig 5).

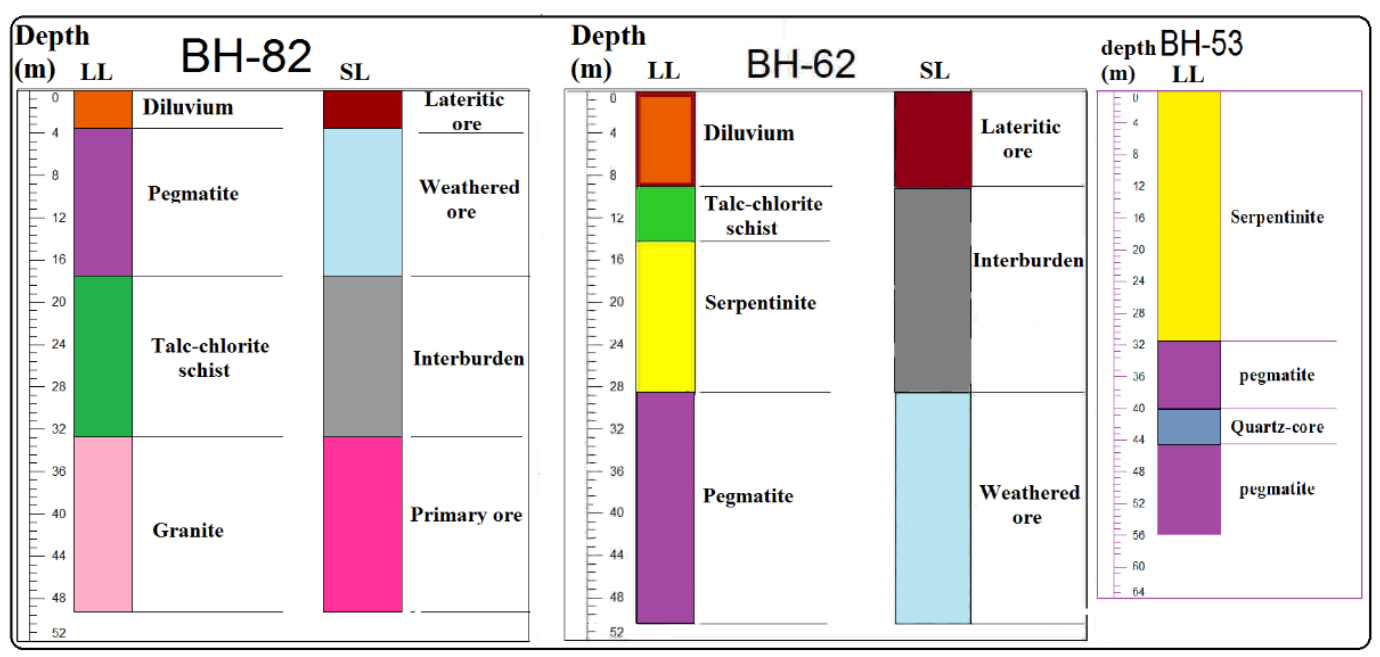

Figure 5. Lithological and stratigraphic logs (LL and SL) of typical boreholes of the mine area, shows thickness of the rocks and hosted ores (data source, EMDSC, 2010).

Lateritic ore is found beneath the overburden (topsoil) and above the weathered ore. Its vertical extension is very shallow compared to the weathered and primary ore types (thickness is varying from $50 \mathrm{~cm}-6 \mathrm{~m}$ ). This type of tantalite ore is enriched with hematite, magnetite and ilmenite and hosted by diluvium (slope-waste) materials. It contains low grade tantalite ore. 
Weathered ore occurs between the lateritic and primary ore and is relatively marked with high grade of tantalite ore $\left(0.018 \% \mathrm{Ta}_{2} \mathrm{O}_{5}\right)$. Its thickness varies from $40 \mathrm{~m}-60 \mathrm{~m}$ and mining is so far confined to this zone.

Primary ore is rich in tantalite with complex Ta-Nb-Li-Be mineralization and hosted by hard granite-pegmatite rocks that need drilling and blasting works to recover the ore. The thickness of the ore varies from $45 \mathrm{~m}$ to $65 \mathrm{~m}$ with an average thickness of $60 \mathrm{~m}$. It is similar in thickness with the weathered type of ore and will be mined in the future.

\section{RESULTS}

\subsection{Open-pit Mine Design}

The open pit design is developed confined to the pegmatite body by considering the data related to the geological structures, geotechnical properities, shape of the orebody (see Fig 4B), slope of the orebody, and basic design parameters. Structurally, the pegmatite is part of Kenticha graben regionally, trending N-S and dipping $30^{\circ}$ east. The orebody is also affected by two minor faults(strike slip faults?) trending NE-SW and NW-SE. The data related to geotechnical properities, coefficients of hardness, and expansion of ore is summarized in tables 1 and 2.

From the field observations and data analysis, free digging of the ore and waste with an excavator is possible when the hardness coefficient of the ore is $\leq 4$ (weathered ore). The ore needs to be fragmented by drilling and blasting when the hardness coefficient value is $>4$ (primary ore). The existing pilot plant is not capable of processing the primary ore as it requires grinding and milling. Therefore, as mining advances and reaches the primary ore with hardness $>4$, the company will have to shift mining operations to other localities where the hardness coefficient is $\leq 4$.

Sections of the bench showing the bench height, bench width and batter angle are shown in figure $6 \mathrm{a}$ while the oveall pit slope angle with the haul road width are shown in figure $6 \mathrm{~b}$. In addition to benches, the haul road design was done using the basic parameters as inputs to GeomCom Surpac-6.5.1software (see Fig 7). All the the design parameters are defined and set based on the basic parameters identified and evaluated in the field. For example, the bench height $(10 \mathrm{~m})$ and bench (berm) width $(8 \mathrm{~m})$ values were specified considering the machinery height and width and nature of the deposit and host rock characterstics (the strength, ore grade and tonnage). It is obvious that the height of the machinery must access easily the ore block found along the crest of the bench and it must 
have proper working face to be able to stand and mine safely (so, the bench widith should be a bit wider than the machinery width).

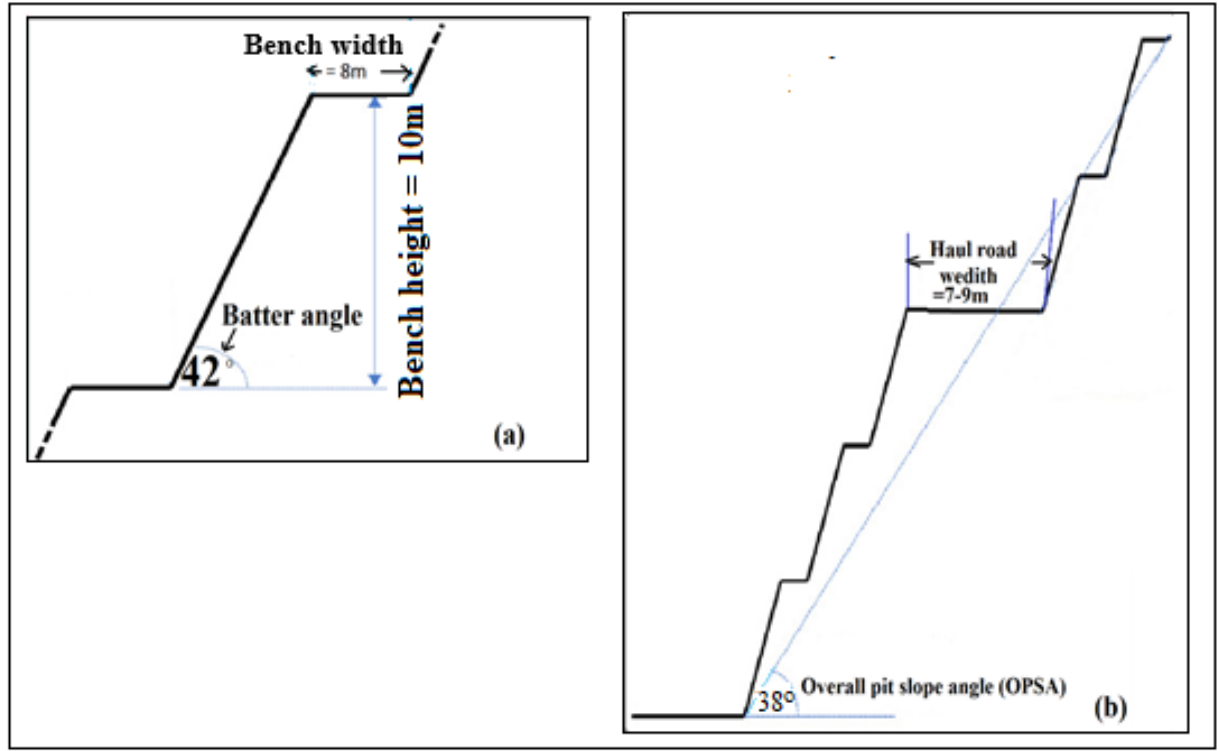

Figure 6. a) Bench design section view of the overall pit design; b) few of the pit design parameters.

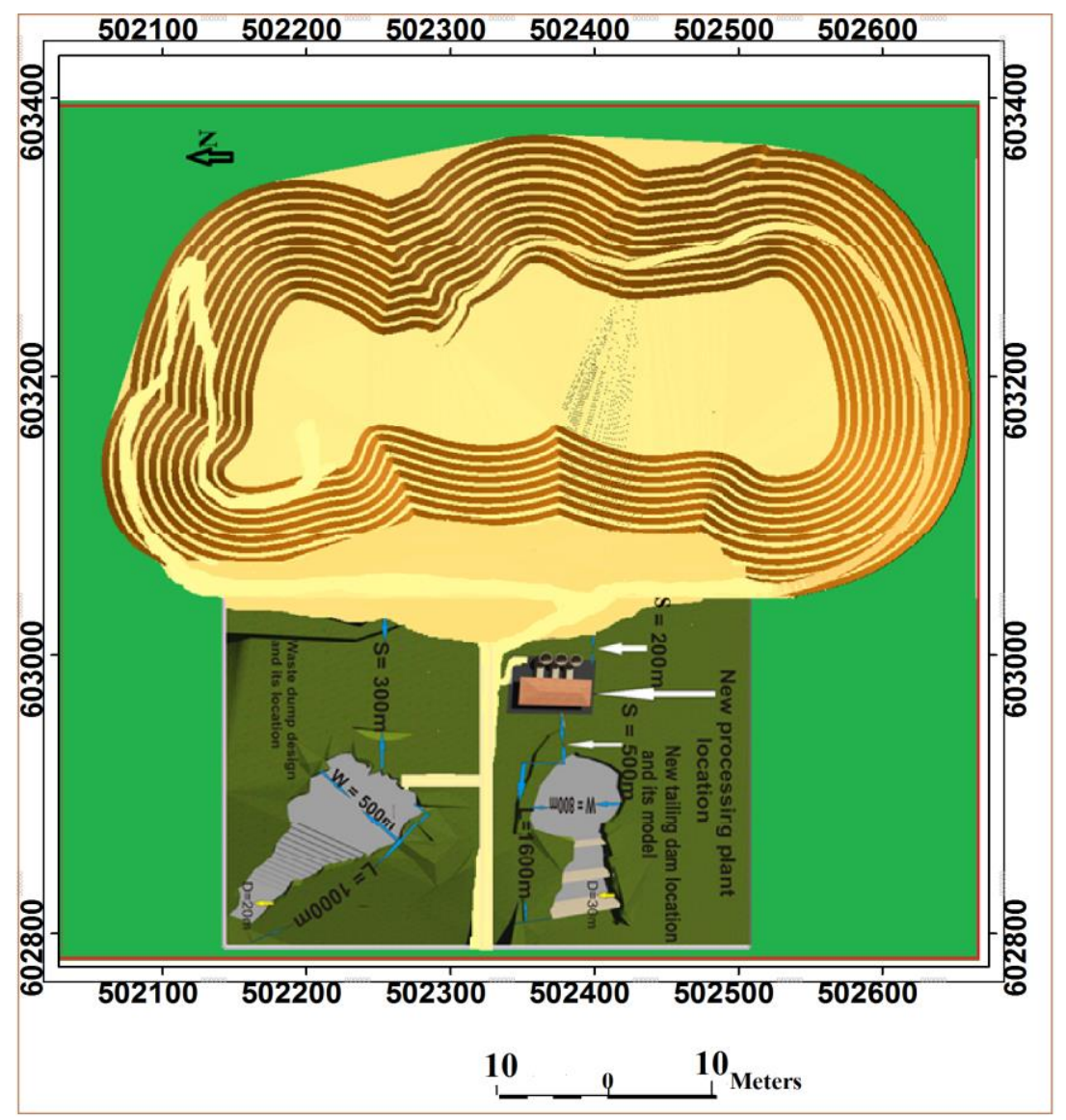

Figure 7. Open pit, haul road and waste dump designs with new processing plant and tailing dam locations. 
The batter (bench face) angle $\left(42^{\circ}\right)$ is specified and fixed as an ideal slope to both the soft and hard ore materials (Fig 7) considering the physical-mechanical characters of the ore and rock, and accordingly the number of benches (11) have been developed. In addition, the over all pit slope angle (OPSA), for the soft and hard rock formation was specified and assigned as $38^{\circ}$ (once the ore material is characterized with the slippery featured talc-chlorite schist unit, the value suits ideal keeping in mind the effect of dilution and safety of the machineries).

The number of benches and bench (berm) width is developed depending on the total thickness of the ore body $(110 \mathrm{~m})$ and the remaining ore thickness $(80 \mathrm{~m})$ to the west of the pegmatite body. Accordingly, 11 benches are developed along the northern, eastern and southern parts of the ore body whereas in the western part, the ore body is already exploited to some depth hence, the number is reduced to eight (Fig 7). Similarly, the haul road (ramp) design is developed together with pit (bench) design, firstly, by defining the input parameters like width which is fixed at 7-9 m considering the trafic flow and the availiable machines and vehicles. Design recommendation for minimum road "running width" is 3.5 times truck width for 2 way ramp straight; 4 times truck width for 2 way ramp corners; $2-2.5$ truck width in one way straights and corners (Holman, 2006; DMIRS, 2016; Kaufman and Ault 1977). The haul road design (Fig 7) also defines an average and maximum slope to be $3 \%$ and $8 \%$ respectively based on the natural topogaphic set up, maintainance cost, safe mining operations, and minimum mining costs. Accordingly, two separate haul roads are developed keeping in mind the ore body length $(\sim 1,000 \mathrm{~m})$ (Fig 4$)$ and the possible location of the future processing plant (Fig 7). This is to minimize the transportation costs and trafic flow. The Western Australian DMIRS traffic management audit guidelines confirm that the road gradients can not be practicable if it exceeds $10 \%$ ( 1 in 10). This is accepted standard gradient in Australia for rigid body dump trucks whereas in North America 1 in 12 ramp gradient is common (DMIRS, 2016).

\section{DISCUSSION}

Owing to high capital requirements, ever-changing economic factors, ensure maximum extraction, low stripping ratio, and slope constraints, the mining companies needs to design an optimized pit that will have high value and stability in the face of these challenges (Aseidu-Asante, 2012). Poor design can have adverse effects such as dilution, ore recovery, profit and even premature closure of the mine in case of unforeseen reduction in metal price. 


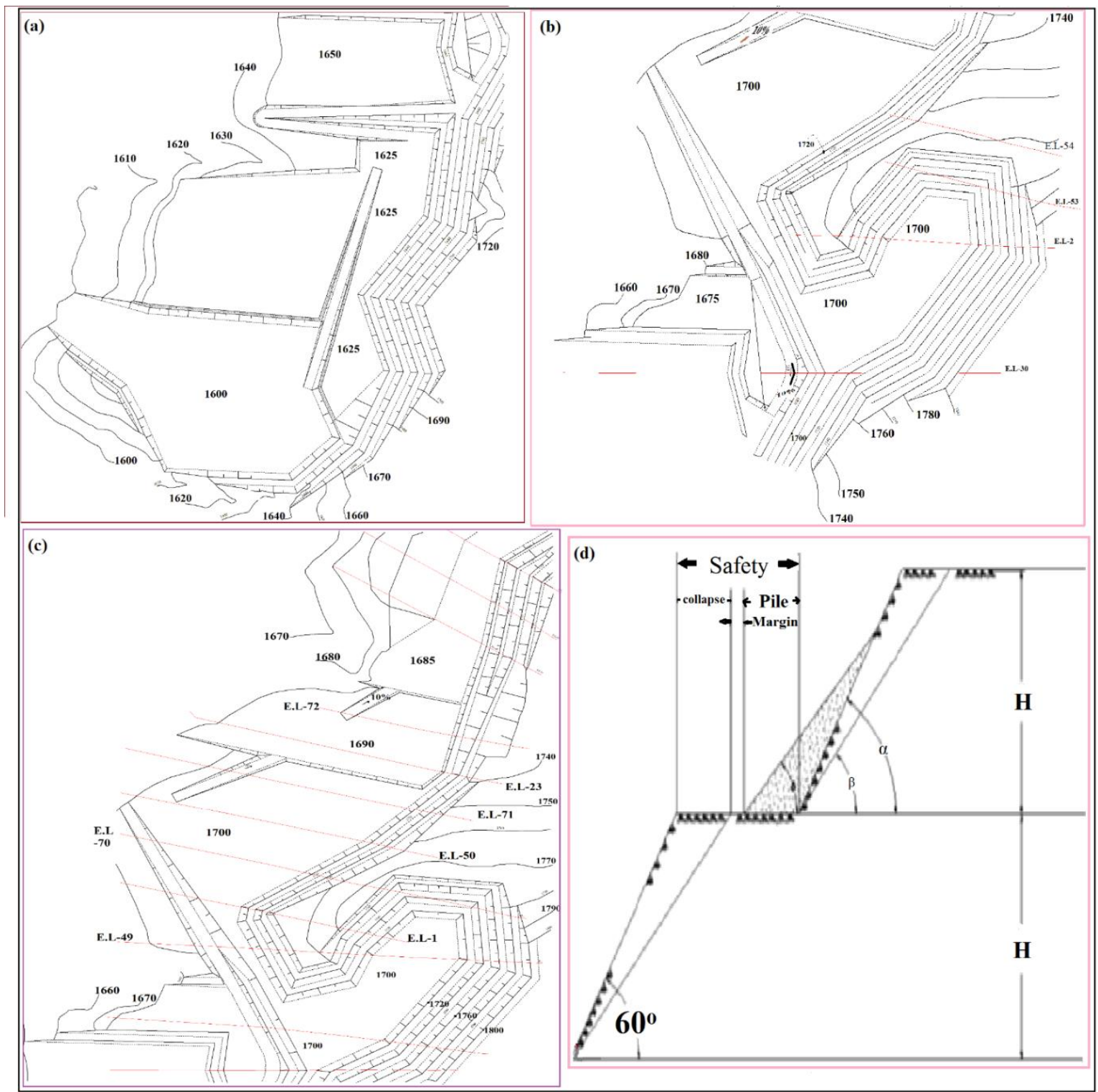

Figure 8. Mine design produced by the company; a) Locality 2; b) Locality 6; c) Locality 7; and d) Safety limit face used in developing the design (Note: Numbers ranging from 1600 to 1800 are mine levels in meters, and EL = Exploration line).

The Ethiopian Mineral Development Share Company had developed an open pit (bench) design for each of the three localities (2, 6 and 7) (Fig 8), though not implemented. The design, for a reserve of 4,937,047t for 3 localities projected an extraction ratio of $90 \%$ and dilution ratio of $10 \%$ (EMDSC, 2012). The design has few shortcomings like, (i) it is developed using Global Mapper 8 where the benches and haul roads are not well defined; (ii) it does not include the primary ore; (iii) it suggests long highwall $(40 \sim 60 \mathrm{~m})$ that extends from locality 2 to 6 and 7, this makes the work place at localities- 6 and 7 very challenging; (iv) it increases mine dilution because of unnecessary intra-burden along the boundary of the 
localities; (v) its pit outline is not well defined (benches are developed only to the eastern part of the ore body); and (vi) it does not properly provide ramp design and haul road, maximum slope used is $10 \%$ and also are not interconnected with successive benches so as to access the desired ore (Fig 8).

An open pit mine requires a haul road network which connects the site of extraction to all possible destinations outside the pit (Yarmuch et al., 2017). In open pit, ramps are roads that connect the working faces to the pit exits, so that large amounts of material can be removed for the construction of the faces.

The suggested optimum open pit design (Fig 7) will overcome all the shortcomings identified in the company mine design (Fig 8). For instance, the suggested design is developed for both the weathered and primary ore body using well defined input design parameters with the help of appropriate mine software tool. Though, the weathered and primary ore bodies have almost the same thicknesses (averaging about $55 \mathrm{~m}$ each), the areal extent of the ore body decreases with increasing depth. Thus, the area of the weathered ore is greater than that of the primary ore.

An approach in which the advantages and disadvantages of utilizing different bench heights in an open pit mine is aggregated in a compromising way and a practical bench height (Soltanmohammadi et al., 2010). For this purpose, the effective criteria in bench height optimization is indicated and categorized in two, economical and technical. In the present case, Gemcom Surpac-6.5.1 software is used to develop the open pit mine design. The parameters used as inputs are bench height $(10 \mathrm{~m})$, bench width $(8 \mathrm{~m})$, bench slope $\left(42^{\circ}\right)$ and the overall pit slope angle $\left(38^{\circ}\right)$ for both soft and hard rock formations. The haul road design developed using widths of $7 \mathrm{~m}$ to $9 \mathrm{~m}$ with an average slope (3\%) maximum being $8 \%$, and curve radius ranging from $9 \mathrm{~m}$ to $12 \mathrm{~m}$. These were integrated with open pit design. The procedures used to develop the optimal open pit design included delineation of the bottom pit limit outline based on the size and shape of the ore body, and checking that the outlined segment is closed. To ensure that the pit limit outline fits perfectly with the ore body, it was checked that the enclosed segments in X-Y (plane view), X-Z (section view) and Y-Z (long section view) are accurate. The segments were smoothed and the bearing distance of the haul road was checked and the in-pit ramps were developed to begin and end perfectly at the pit crest and pit bottom. Though, the open pit mine is designed using the data from the three localities, it can be expanded in future to cover all portions of the ore body. It is significant to note that most of the areas underlying the present processing plant are minable. Therefore, it 
may be necessary to re-evaluate the volume of the underlying ore material and to relocate the processing plant. Finally, it is estimated that about 5-10\% of ore may be recovered with the newly proposed design.

\section{CONCLUSIONS}

Tantalite ore at Kenticha mine is mined using open pit mining method. At present open pit mining method is being done without a proper design of the pit and is not systematic and irregular extraction of only the high-grade ores. This is causing dilution (5-10\%) and ore losses. At present, mining is being done at localities 2, 6 and 7 and mainly the weathered ore. An optimum open pit mine design is developed considering the ideal design parameters like average bench face angle for both the soft and hard rock formation $\left(42^{\circ}\right)$, overall pit slope angle for both the soft and hard rock formation $\left(38^{\circ}\right)$, and using Gemcom Surpac-6.5.1 software. These specified values were found suitable in reducing the dilution, and possibility of slope failures. Also, the proposed design has taken into account the shortcomings of the company's design, though not yet implemented. The suggested pit design and extraction sequence will reduce the ore dilution levels is expected to increase the tantalite concentrate by $5-10 \%$.

\section{ACKNOWLEDGEMENTS}

This paper forms part of MSc thesis titled "Evaluation of mining and processing methods in tantalite open-pit mine, Kenticha, southern Ethiopia”. It was funded by the recurrent budget of College of Natural and Computational Sciences, Mekelle University. The financial support is duly acknowledged. The support and sharing of data by the Ethiopian Mineral Development Share Company is highly appreciated and duly acknowledged.

\section{CONFLICTS OF INTERESTS}

No Conflict of Interests

\section{REFERENCE}

Akisa, D. M \& Mireku-Gyimah, D. 2015. Application of Surpac and Whittle Software in Open Pit Optimisation and Design. Ghana Mining Journal, 15(1): 35-43. 
Amankwah, H. 2011. Mathematical Optimization Models and Methods for Open-Pit Mining, Unpublished PhD Dissertation, Department of Mathematics, Linköping University of Sweden, 38p.

Armstrong, D. 1990. Definition of mining parameters. Surface Mining (2nd Edition), SMEOnline Digital Library.

Aseidu-Asante, S.K. 2012. Computer Aided Open Pit Optimisation and Design. Unpublished Lecture Notes for MSc in Mining Engineering, University of Mines and Technology, Tarkwa, Ghana, 72p.

Boachie, S. 2013. Optimised Open Pit Design Using Minesight Software-A case study at Bisha Mining Share Company, Eritrea, East Africa. MSc Thesis, University of Mines and Technology, Tarkwa, Ghana, 114p.

DMIRS, 2016. Traffic management audit-guide. Dept. of Mines, Industry Regulation \& Safety, (www.dmp.wa.gov.au/Documents/Safety/MSH_AuditGuide_TrafficManagement.pdf).

Dongboi, M. M. 2013. Optimisation and Design of Open Pit of the Camplebell Town Ridge Deposit at London Mining Company Limited, Sierra Leone. MSc Thesis, University of Mines and Technology, Tarkwa, Ghana, 71p.

EMDSC (Ethiopian Mineral Development Share Company). 2010. Opportunities for Tantalum resources development in Ethiopia, Addis Ababa, Ethiopia. Technical report (unpubl.).

EMDSC (Ethiopian Mineral Development Share Company). 2012. Technical tantalum mining report. Kenticha, Addis Ababa, Ethiopia (unpubl.).

EMDSC (Ethiopian Mineral Development Share Company). 2013. Surface mine working report in Localities 2, 6 and 7 at Kenticha mine, Addis Ababa, Ethiopia (unpubl.).

Ebrahimi, A. 2013. The importance of dilution factor for open pit mining projects, West Hastings Street, Canada.

Elias, I. K. 2013. Optimisation and Design of an Open Mine: A Case Study. Unpublished MSc Thesis, University of Mines and Technology, Tarkwa, 69p.

Frempong-Boakye, V. 2004. Application of Surpac and Whittle Software in Open Pit Design:

A Case Study. Unpublished MSc Thesis, University of Mines and Technology, Tarkwa, pp. 99-100.

Holman. 2006. Caterpillar Haul Road Design and Management. www.directminingservices.com/ wp-content/uploads/2010/06/CAT-Haul-Road-Design.pdf. 
Kaufman W.W \& Ault J.C. 1977. Design of surface mining haulage roads - a manual. U.S. Department of Interior, Bureau of Mines, Information Circular 8758. https://www.osmre.gov/resources/library/ghm/haulroad.pdf.

Ramazan, S. 2007. The New Fundamental Tree Algorithm for Production Scheduling of Open Pit Mines. European Journal of Operational Research, 177(2): 1153-1166.

Ramazan, S \& Dimitrakopoulos, R. 2013. Production Scheduling with Uncertain Supply: A New Solution to the Open Pit Mining Problem. Optimisation and Engineering Journal, 14: 361-380 (https://doi.org/10.1007/s11081-012-9186-2).

Soltanmohammadi, H., Osanloo, M., Sami, A \& Malekzadeh, S. 2010. Selection of practical bench height in open pit mining using a multi-criteria decision-making solution. Journal of Geology and Mining Research, 2(3): 48-59.

Tadesse, S. 2009. Mineral Resources Potential of Ethiopia. Addis Ababa University Press (https://scholar.google.com/scholar?hl=en\&as_sdt=0\%2C5\&q=Tadesse $\% 2 \mathrm{C}+\mathrm{S} .+200$ 9.+Mineral+Resources+Potential+of+Ethiopia).

United States of Geological Survey. 2014. Global tantalum producing countries [Ta\%20general\%20info/8\%20Top\%20Tantalumproducing\%20Countries\%20\%20Pg. 3\%20-\%20TheStreet.htm]. [Accessed 5-4-2020].

Weldegebrial, H., Bheemalingeswara, K \& Zerihun, D. 2020. Evaluation of mining and mineral processing methods' impact on tantalite concentrate in Kenticha open pit mine, southern Ethiopia. Journal of Applied Earth Science, 129(4): 205-216 (https://doi.org/10.1080/25726838.2020.1806676).

Yarmuch, J., Epstein, R., Cancino, R \& Pẽ na, J. C. 2017. Evaluating crusher system location in an open pit mine using Markov chains. International Journal of Mining, Reclamation and Environment, 31(1): 24-37.

Zerihun, D., Garbarino, C \& Valera, R. 1995. Granite pegmatite system in Kenticha (Adola, Sidamo, Ethiopia) rare metal pegmatite belt: petrochemistry, regional pegmatite zoning and classification. SINET: Ethiopian Journal of Science, 18: 119-157. 
Appendix 1. Exploration and mining related data of tantalite ore of the Kenticha Mine (EMDSC, 2013).

\begin{tabular}{|c|c|c|c|c|c|}
\hline $\begin{array}{l}\text { Locality } \\
\text { No. }\end{array}$ & E.L & $\begin{array}{c}\text { Bore holes } \\
\text { drilled }\end{array}$ & Pits tests & $\begin{array}{c}\text { Mine level ranges } \\
(\mathrm{m})\end{array}$ & $\begin{array}{c}\text { Total grades of } \\
\operatorname{Ta}_{2} \mathrm{O}_{5}(\%)\end{array}$ \\
\hline \multirow{9}{*}{2} & 33 & - & 6 & $1610-1660$ & 0.0276 \\
\hline & 15 & 4 & 14 & $1595-1690$ & 0.09 \\
\hline & 14 & - & 20 & $1610-1690$ & 0.0158 \\
\hline & 3 & 7 & 18 & $1605-1710$ & 0.099 \\
\hline & 12 & - & 16 & $1620-1740$ & 0.070 \\
\hline & 13 & 4 & 14 & $1635-1740$ & 0.079 \\
\hline & 36 & - & 15 & $1630-1750$ & 0.045 \\
\hline & 22 & 5 & 19 & $1632-1754$ & 0.043 \\
\hline & 31 & - & 16 & $1640-1760$ & 0.021 \\
\hline \multirow{4}{*}{6} & 54 & - & 9 & $1650-1760$ & 0.038 \\
\hline & 30 & 2 & 13 & $1640-1755$ & 0.037 \\
\hline & 2 & 5 & 15 & $1668-1760$ & 0.05 \\
\hline & 53 & 4 & 14 & $1675-1780$ & 0.063 \\
\hline \multirow{7}{*}{7} & 49 & 2 & 9 & $1700-1800$ & 0.028 \\
\hline & 1 & 4 & 10 & $1703-1760$ & 0.014 \\
\hline & 70 & - & 12 & $1790-1810$ & 0.017 \\
\hline & 50 & 4 & 13 & $1680-1770$ & 0.023 \\
\hline & 71 & - & 13 & $1690-1760$ & 0.0187 \\
\hline & 23 & 3 & 14 & $1680-1740$ & 0.017 \\
\hline & 72 & - & 14 & $1685-1720$ & 0.016 \\
\hline Total & 20 & 44 & 274 & & \\
\hline
\end{tabular}

